\title{
Diversity and dynamics of the fungal community in Lake Ohrid
}

\author{
Ljiljana Čomić ${ }^{1, *}$, Branislav Ranković ${ }^{1}$, Vera Novevska ${ }^{2}$, Aleksandar Ostojićc ${ }^{1}$ \\ ${ }^{1}$ Faculty of Science, University of Kragujevac, Radoja Domanovića 12, 34000 Kragujevac, Serbia \\ ${ }^{2}$ Hydrobiological Institute, 6000 Ohrid, Republic of Macedonia
}

\begin{abstract}
Fungi are universally present in freshwater systems and are of great significance in the structural and functional organization of these ecosystems. The aim of this study was to assess the diversity of fungal communities in the ancient, oligotrophic Lake Ohrid and to investigate their spatial and temporal dynamics. The fungal community in Lake Ohrid consists of 36 species identified from 213 isolates. The autochthonous community is made up of 10 species belonging to the orders Saprolegniales and Peronosporales: Achlya americana, A. racemosa, Aphanomyces leavis, Dictyuchus monosporus, D. sterile, Pythium ultimum, Saprolegnia ferax, S. hypogina, S. monoica, and Saprolegnia sp. The allochthonous community is composed of 26 species from 15 genera of fungi. The dominant genera are Aspergillus (5 species, $13.86 \%$ of determined species), Penicillium (6 species, $16.66 \%$ ), and Cladosporium and Fusarium (3 species, $8.33 \%$ ). The species Kloeckera apiculata, Didiostible sp., Gliocladium roseum, and Varicosporium delicatum are identified here for the first time in freshwater ecosystems of the Balkans. Quantitative analysis of the fungal community showed that the number of propagules varied in the range of 0 to $19.5 \times 10^{3} \mathrm{l}^{-1}$. The diversity and abundance of both the autochthonous and the allochthonous fungal communities are greater in the littoral than in the pelagial zone. Our results represent the first hydromycological data for Lake Ohrid the region of Macedonia.
\end{abstract}

KEY WORDS: Lake Ohrid · Fungal community · Aquatic fungi

Resale or republication not permitted without written consent of the publisher

\section{INTRODUCTION}

Fungi are universally present in freshwater systems and are of great significance in the structural and functional organization of these ecosystems. Aquatic fungi contribute to the energy flow and productivity of ecosystems through their active role in the utilization and biodeterioration of organic matter (Khulbe 2001). They produce a wide range of ectoenzymes and participate in degradation of recalcitrant macromolecules in aquatic ecosystems (Chamier 1985, Lynd et al. 2002, Perez et al. 2002, Schoenlein-Crusius \& PiccoloGrandi 2003, Artigas et al. 2004). The fungi encountered in freshwater are divided into 2 principal groups: autochtonous aquatic fungi whose life cycle is specifically adapted to the aquatic environments (zoosporic fungi of Chytridiomycetes and Oomycetes) and allochthonous fungi, mainly terrestrial, filamentous hypho- mycetes belonging to the Deuteromycotina (Fungi imperfecti), which are not especially adapted to an aquatic existence but whose life cycle may be completed in water if an adequate supply of nutrients is available (Ranković 2004, Prasad et al. 2007, Shearer et al. 2007).

Aquatic fungi are predominantly saprophytes, but some of them possess the ability to parasitize some other hydrobionts, causing epiphytoses, mycoses and other conditions (Sigee 2005). For example, fungal parasitism can have a significant effect on interspecies competition of algae due to the degree of specificity in the alga attacked (Sen 1988a,b). Quite often, the parasitic fungi cause epidemic infections in zooplankton, resulting in substantial disturbances in the trophic chain of aquatic cenoses (Voronin 2008).

Even though a number of authors have pointed out the sensitivity of fungi to changes in ecological condi- 
tions as well as their rapid reaction to environmental changes (Dick 2001, Tsui et al. 2001, Prasad et al. 2007, Paliwal \& Sati 2009), to date fungi have not been sufficiently validated as bioindicators of water quality. In view of the current growing contamination of aquatic ecosystems, the role of fungi in the biodegradation of particular effluents becomes increasingly interesting. Some aquatic fungi have been reported to be able to degrade nonyphenol, detergents, xenobiotics, and petroleum hydrocarbons (Steciow 2002). For these reasons, the study of aquatic fungi (along with other traditional components of aquatic ecosystems) is considered to be an important direction in the development of hydrobiological research.

Lake Ohrid is an ancient lake that formed tectonically in the Pliocene (between 4 and 10 million yr ago). Due to its age, its geographical isolation, as well as the permanency of life conditions, a relatively high number of lake organisms are still speciating. Lake Ohrid represents a refugium for numerous relict species or 'living fossils,' whose close relatives can only be found as fossil remains in other parts of Europe (Spirkovski et al. 2001). The main characteristic of this lake is its endemism: out of approximately 1200 species found in the lake, at least 212 are endemic (Salemaa 1994, Albrecht \& Wilke 2008). Endemic species cover the complete food chain, from phytoplankton (e.g. Cyclotella fottii) through zooplankton (e.g. Cyclops ochridanus), cyprinid fish (e.g. Pachychilon pictus), predatory fish (e.g. Salmo letnica), and finally to its diverse endemic bottom fauna (e.g. Ochridagammarus solidus). Current knowledge related to the biodiversity of Lake Ohrid does not, however, include data about fungal communities.

The aim of the present work was to assess the diversity of fungal communities in the oligotrophic Lake Ohrid and to investigate their spatial and temporal dynamics. Our results represent the first data on the fungal community in this ancient lake, as well as a new contribution to its biodiversity investigation. Our results are also the first hydromycological data for Macedonia.

\section{MATERIALS AND METHODS}

Study site. Lake Ohrid is the largest (surface area $358 \mathrm{~km}^{2}$ ) and the deepest (maximum depth $296.7 \mathrm{~m}$ ) lake in the Dassaret lake group in the Aegean lake zone and is one of the most voluminous lakes in Europe (volume $54.9 \mathrm{~km}^{3}$ ). It is situated in the Sar-Pindhos system in karstic, or limestone, bedrock. Lake Ohrid qualifies as oligotrophic, both in terms of nutrient concentration (4.5 $\mathrm{gg} \mathrm{l}^{-1}$ of phosphorus), as well as biological parameters. Despite the lack in annual deepwater ex- change from complete overturn or plunging rivers, dissolved oxygen never drops below $\sim 6 \mathrm{mg} \mathrm{l}^{-1}$ (Novevska 2006, Matzinger et al. 2007). With its geological, hydrographical and biological characteristics, it represents an ecosystem of special significance. It was declared a World Heritage site by UNESCO in 1979.

Sample collection. The diversity of fungal communities and their spatial and temporal dynamics were studied in Lake Ohrid. Water samples were collected monthly during the vegetation period, from March to October, 2006.

Five permanent sampling sites were selected for mycological research (Fig. 1). Sampling locations were selected so as to reflect different ecological features, with 1 site in the pelagial zone (P) and 4 sites in the littoral zone: Grasnica (G), the zone of the Volgoska River's inflow, receiving industrial wastewaters and waters from some settlements; Ohrid Bay (O), near the city port; Sileks (S), a zone of sandy beaches in the

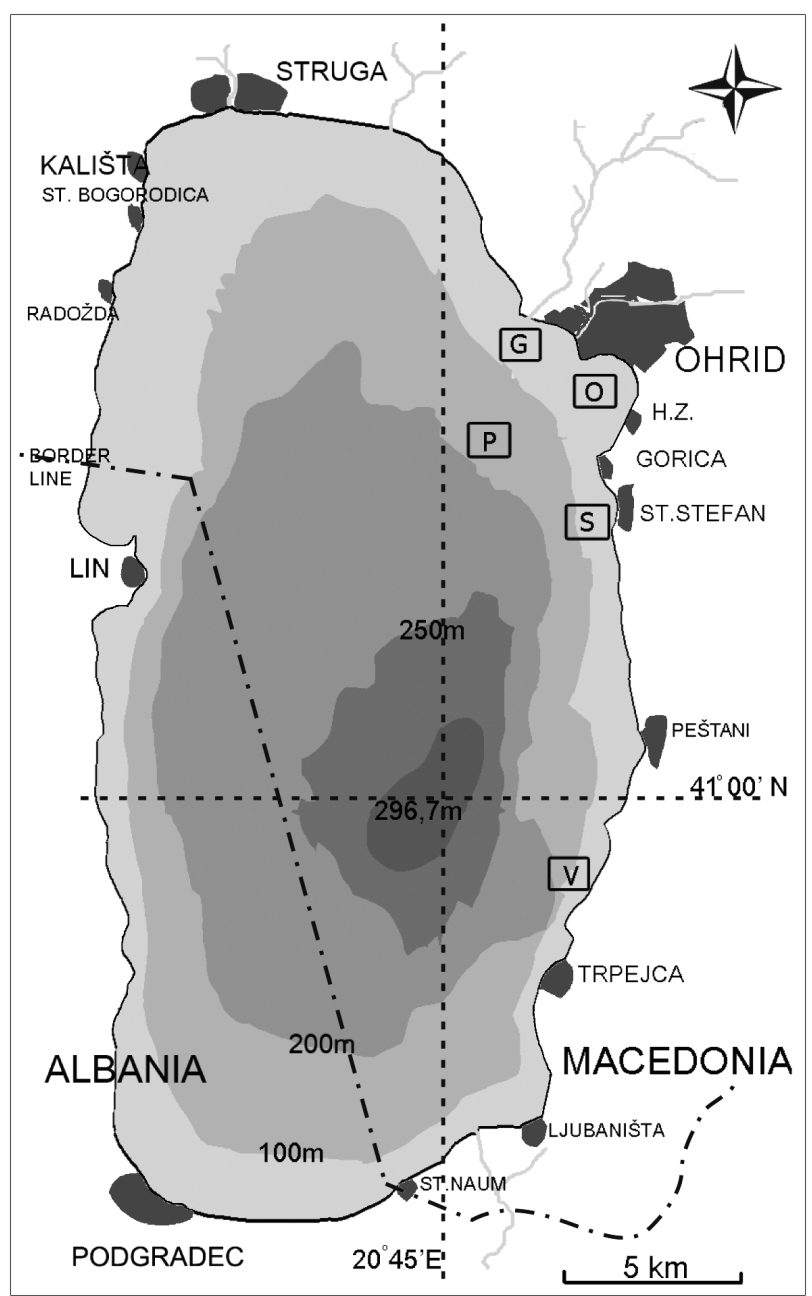

Fig. 1. Morphometric map of Lake Ohrid, with locations of the sampling sites in the pelagial (P) and littoral zones (G: Grašnica, O: Ohrid Bay, S: Sileks, V: Velidab) 
eastern part of Lake Ohrid, near a tourist-recreation complex; and Velidab (V), the cleanest part of the lake with a rocky floor and steep bank, in a location characterized by numerous sublacustrine springs.

Water samples were collected with a 21 Ruttner sampler, from depths of 0.5 and $3 \mathrm{~m}$ in the littoral zone and $0.5,15,25,50,75,100$, and $150 \mathrm{~m}$ in the pelagial zone.

Laboratory procedures. Water samples were processed on the same day they were collected, for both autochthonous and allochthonous fungal species.

The autochthonous fungal species were isolated using the baiting technique (Arnold 1968, Dix \& Webster 1995). A $50 \mathrm{ml}$ aliquot of each water sample was baited with different sterilized baits and incubated at $25^{\circ} \mathrm{C}$ for $3 \mathrm{wk} ; 3$ different substrates were used for baiting: seeds of Cannabis sativa, cellophane and nail pieces. The growth of the fungi on these baits was controlled on a daily basis. The developed fungi were then studied by direct microscopic examination.

The allochthonous fungal species were isolated using the dilution plate technique. Both 1 and $2 \mathrm{ml}$ from each sample were inoculated on malt-agar culture media in Petri dishes, with 3 replications. Previously, streptomycin (Galenika) had been added to the culture media to prevent bacterial contamination. All cultures were incubated at $25^{\circ} \mathrm{C}\left( \pm 2^{\circ} \mathrm{C}\right)$ under day-night light exposure for $7 \mathrm{~d}$, after which the number of propagules was determined. Pure cultures were isolated according to standard mycological methods by reseeding on selective substrates: potato-dextrose agar (PDA), Czapek's agar (CzA), and malt agar (Booth 1971). Stock cultures were kept in the culture collection of the Faculty of Science, Institute of Biology, Kragujevac.

Isolated species were identified according to the following literature: Middleton (1943), Raper \& Thom (1949), Cooke (1963), Raper \& Fennel (1965), Coker (1969), Seymour (1969), Gilman (1971), Batko (1975), Ingold (1975), Barnet \& Hunter (1998), Khulbe (2001), Dugan (2006).

Data analysis. For allochthonous species, dominance (d) was calculated according to the formula given by Tischler (as cited by Schwerdtfeger 1975):

$$
d=\frac{a_{i}}{\sum_{i=1}^{n} a_{i}}
$$

where $a_{i}$ is number of individuals of a given species, and $\Sigma a_{i}$ is the number of individuals of all species.

For each taxon, frequency (F) was calculated according to the formula given by Merkamale (as cited by Schwerdtfeger 1975):

$$
\mathrm{F}=b / a \times 100
$$

where $a$ is the total number of samples, and $b$ is the number of samples in which a given taxon is recorded.
In comparing the qualitative composition of the fungal community in different sampling sites during the investigation period, the Sørenson similarity index $(S)$ (Sørensen 1948) was used:

$$
S=\frac{2 c}{a+b}
$$

where $a$ is the number of species present in locality A, $b$ is the number of species in locality $\mathrm{B}$, and $c$ is the number of species that localities A and B have in common.

Analysis of variance (ANOVA) was used to test the differences between communities at different sites. For multiple comparisons, a Fisher's least significant difference (LSD) test was used. P-values $<0.05$ were considered to be significant. Cochran's test was performed to test for differences in the appearance of the fungal taxa on a monthly basis. Statistical analysis was performed by SPSS (version 16.0).

\section{RESULTS}

The fungal community in Lake Ohrid consists of 36 species identified from a total of 213 isolated cultures (Table 1).

\section{Diversity of the autochthonous fungal community}

The autochthonous fungal community included 10 species with biflagellate zoospores belonging to the orders Saprolegniales and Peronosporales, found in $50.89 \%$ of the tested water samples. The dominant genus was Saprolegnia, whose species were found in $20.53 \%$ of the samples. $S$. ferax is the most frequently occurring and widely disseminated species of this genus. It was found at all of the investigated localities throughout the whole vegetation period. $S$. hypogina and $S$. monoica were occasionally found in spring in the part of the littoral that was not subject to eutrophication. Of the genus Achlya, the best represented species was $A$. americana, which was identified in $5.12 \%$ of the tested samples. A. racemosa was found only sporadically in the littoral zone in early spring. Dictyuchus sterile and D. monosporus were each found in $2.56 \%$ of the samples; both species were found in the littoral during the autumn. The most frequently encountered species in Lake Ohrid was Pythium ultimum, which was identified in $13.67 \%$ of the samples, mostly in the water of littoral zone. Aphanomyces laevis, which was previously rarely found in waters of the Balkans, was found in $5.33 \%$ of the samples from Lake Ohrid, always in parts of the littoral that were subject to eutrophication. 
Table 1. Diversity of fungi in Lake Ohrid and their spatial distribution in the pelagial (at depths of $0.5,15,25,50,100$, and $150 \mathrm{~m}$ ) and the littoral (in localities Grasnica, Ohrid Bay, Sileks and Velidab, at depths of 0.5 and $3 \mathrm{~m}$ for each locality) zones, their dominance (D: dominant taxa $5.0 \leq d<9.9 \%$; Sd: subdominant taxa, $2.0 \leq d<4.9 \%$; R: recent taxa, $1.0 \leq d<1.9$; Sr: subrecent taxa, $d<1.0 \%$ ), and frequency (for all identified species, the frequency of occurrence, $\mathrm{F}$, was $<25 \%$ )

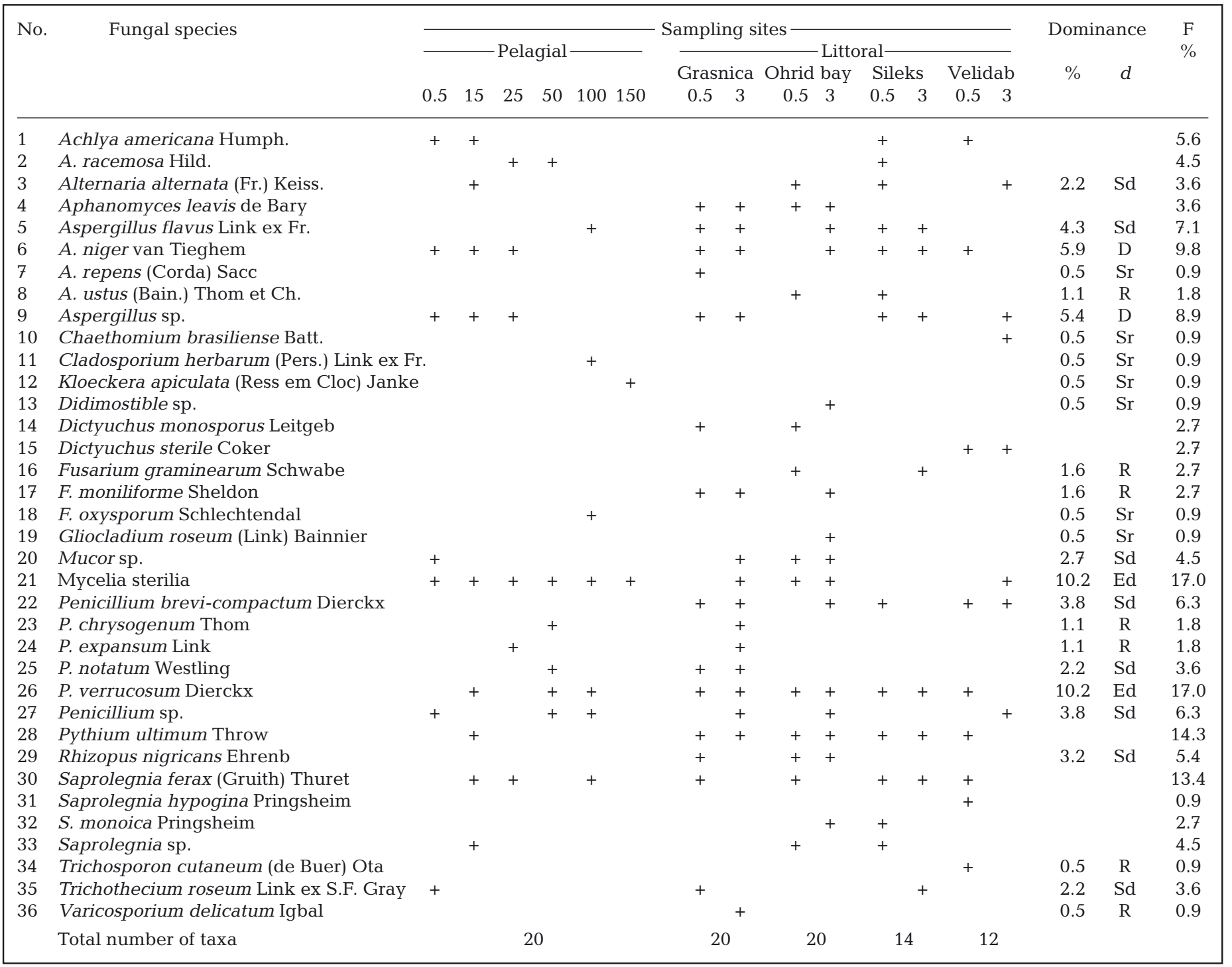

\section{Allochthonous fungal community}

Allochthonous fungi, which include mainly terrestrial species, filamentous hyphomycetes, were identified in $72.3 \%$ of the tested water samples.

The allochthonous fungal community in Lake Ohrid consists of 26 identified species from 20 genera (Table 1). A number of isolates (47) were not identified due to the absence of fructification, and were therefore represented as mycelia sterilia. The majority of species of allochthonous fungi in the lake were found rarely or individually, and only representatives of a few genera showed a fairly massive presence. The dominant genera were Penicillium (present in
$35.02 \%$ of the tested samples), Aspergillus (27.35\%), and Fusarium $(5.98 \%)$. The genus Penicillium was present in $19.24 \%$ of isolated cultures. The most widely disseminated species of this genus were $P$. verrucosum var. cyclopium, $P$. brevi-compactum, and $P$. chrysogenum. The genus Aspergillus included 15.23\% of isolates, with the best represented species being $A$. flavus and $A$. niger. The genus Fusarium included $8.33 \%$ of determined fungi, the most frequently occurring species being $F$. moniliforme. The species appearing with the next greatest frequency were Alternaria alternata, Mucor sp., and Trichothecium roseum, while species of other genera were found individually and sporadically. 
Among the aquatic fungi identified, the species Kloeckera apiculata, Didimostible sp., Gliocladium roseum, and Varicosporium delicatum were recorded here for the first time for freshwater ecosystems of the Balkans. $K$. apiculata was the only species identified in the pelagial zone, at a depth of $150 \mathrm{~m}$. However, due to the low presence of this species, it was impossible to link its distribution with the nature of organic matter or values of ecological factors. Didimostible sp., G. roseum, and V. delicatum were found in the littoral zone, in the part of the lake subject to eutrophication.

The number of propagules found in water samples was in the range of 0 to $19.5 \times 10^{3} \mathrm{l}^{-1}$ and varied as a function of time and locality. The number of propagules ranged from 0 to $19.5 \times 10^{3} \mathrm{l}^{-1}$ in the littoral zone and from 0 to $10.5 \times 10^{3} \mathrm{l}^{-1}$ in the pelagial zone. In the littoral zone, sporogenic fungi were more abundant in parts of the lake overgrown with macrovegetation, as well as in parts subject to human influence and characterized by increased eutrophication. It was impossible to establish any regularity of propagule distribution in relation to water depth. Maximum propagule abundance was recorded in spring and fall, whereas during summer, propagules were not found or else were present in small numbers. Such a temporal distribution is unquestionably linked with climatic factors and with washing of allochthonous material from the shore during periods of heavy precipitation. Comparative analysis of propagule abundance and the spatial distribution of identified fungi indicated greater abundance and diversity of the allochthonous community in the littoral than in the pelagial zone. Such a condition may be linked with the introduction of allochthonous organic matter and with the development of algae and macrophytic vegetation.

\section{Ecological analysis}

Of 36 fungal species found in Lake Ohrid, 17 were recorded both in pelagial and littoral zones. Calculation of the Sørensen similarity index gave a value of $\mathrm{S}=64.3 \%$ for the two zones. The values of the Sørensen similarity index for the pelagial zone and for each of the localities in the littoral zone were between 40.0 and $56.4 \%$. The values for mutual comparison of different localities in the littoral were between 43.2\% (Sileks-Grasnica) and 63.4\% (GrasnicaOhrid Bay).

ANOVA did not show a significant difference in the number of species detected between locations ( $\mathrm{p}=$ 0.121). However, an LSD test showed a significant difference between the pelagial zone and Sileks $(p=0.039)$ and between the pelagial zone and Velidab $(p=0.014)$.
We found that the greatest diversity occurred during spring and fall, and the lowest diversity was recorded during July. The number of recorded species, referring to all sites, varied between 5 in July and 23 in September. Cochran's test, applied for all months (March to October), showed a significant difference between months ( $\mathrm{p}<0.0005)$. Cochran's test, applied to 2 months, showed significant differences between July and September $(p<0.0005)$ and between August and September $(\mathrm{p}<0.0005)$.

\section{DISCUSSION}

The fungal community in Lake Ohrid consists of 36 species, 10 of which are autochthonous aquatic species, while 26 are allochthonous species of terrestrial origin. Lake Ohrid is a newly described habitat for the identified species of fungi. Among the identified fungi, the species Kloeckera apiculata, Didimostible sp., Gliocladium roseum, and Varicosporium delicatum are newly described for freshwater ecosystems of the Balkans.

Composition of the autochthonous fungal community of Lake Ohrid, in which species of the genera Saprolegnia and Achlya are dominant, is similar to that of the corresponding community in Lake Skadar (Ristanovic 1981), Lake Sjenica (Ranković 2004), some lakes in Poland (Czeczuga 1991a,b) and Estonia (Voronin 1989), and some freshwater systems in North and South America (Schoenlein-Crusius \& Piccolo-Grandi 2003).

For species found in Lake Ohrid during this research, others have previously described their different roles in the function of aquatic ecosystems (Sen 1988a,b, Voronin 2008). Most of these species are saprophytic, but there are also some potential phytopathogens (Achlya racemosa, Pythium spp.), as well as animal pathogens (Aphanomyces laevis, Dictyuchus monosporus, Saprolegnia spp.). Moreover, it is possible that the lake is habitat for more fungi whose existence is linked with a host (epibionts, parasites) and whose zoospores are not found free in the water.

Analysis of spatial dynamics indicates greater diversity of the autochthonous community in the littoral than in the pelagial zone. Given that the majority of these species are saprophytic, such a spatial distribution is probably controlled by the presence of an appropriate substrate (Czeczuga \& Muszyńska 2004). Aquatic hyphomycetes are generally associated with clean and well-aerated freshwaters and are believed to be sensitive to pollution (Bärlocher 1992). The increase of nitrogen and/or phosphorus concentration in oligotrophic freshwaters has been reported to increase species richness (Gulis \& Suberkropp 2003). In Lake Ohrid, we found that Achlya americana and Saproleg- 
nia hypogina were always present in parts of the lake with low nutrient concentration, while Aphanomyces laevis was invariably found in parts subject to eutrophication. Pythium ultimum was exceptionally constant in the littoral zone. Pythium spp. are little-specialized pathogens that can cause mass infections of Chlorophyta, Rhodophyta, and Cyanobacteria.

The allochthonous fungal community in Lake Ohrid is mainly composed of terrestrial species washed into the lake from the ground around it and species arriving with remnants of plants found in its immediate surroundings. According to Suberkropp (1991), leaf remnants in the water significantly influence the presence of fungi and their sporulation. Fungi of the genera Trichoderma, Fusarium, Mucor, and Verticillium were previously isolated from decaying leaves (Attili \& TaukTornisiello 1994), which can also explain their presence in Lake Ohrid. The abundance of fungi in Lake Ohrid is similar to that of fungi in lakes of the Neretva River delta (Ristanovic 1973) and in Lake Sjenica (Ranković 2004), but lower than the values found in Lake Skadar (Ristanovic 1981) or in eutrophic lakes (Čomić et al. 1996, Ranković 1998, Semenova \& Terekhova 1990). In a study of saprophytic fungi in Estonian lakes, Voronin (1989) found a close correlation between the number of sporogenic fungi and the content of organic carbon in the water.

The majority of species making up the allochthonous fungal community in Lake Ohrid are widespread and have been previously recorded both in lakes of Southeast Europe (Ristanovic 1981, Čomić et al. 1996, Ranković 1998, 2004) and in other parts of Europe, North and South America, and Africa.

Several studies have suggested that aquatic fungi produce a wide range of ectoenzymes and that they are able to degrade recalcitrant macromolecules such as cellulose (Thompstone \& Dix 1985, Carlile \& Watkinson 1997, Lynd et al. 2002), hemicellulose, pectin (Chamier\& Dixon 1982), and probably lignin (Marvanová 1997, Perez et al. 2002). A certain number of taxa isolated from Lake Ohrid were previously reported to possess the ability to degrade cellulose (Chaetomium, Penicillium, Fusarium, Pythium), pectin (Aspergillus niger and Rhizopus), and lignin (Chaetomium and Aspergillus). According to Kiziewicz \& Kurzàtkowska (2004), species of Aphanomyces, Saprolegnia, and Pythium are able to degrade chitin.

According to the ecological classification of heterotrophic microorganisms of Park (1972), the bulk of isolated species belong to the category of transient accidental microorganisms, probably migrants. Transient accidental microorganisms can either develop, or lack, sporadic activity.

The qualitative composition of the fungal community in the littoral and pelagial zones shows a relatively high value of the Sørensen similarity index ( $\mathrm{S}=64.3)$. When the qualitative composition of fungi in the pelagial zone is compared separately to each of the localities in the littoral, the lowest value of Sørensen index is noted for Ohrid Bay ( $\mathrm{S}=40.0 \%$ ). Although, both in the pelagial zones and in Ohrid Bay, the same number of taxa was identified (Table 1), the differences between them, as well as the low similarity index, point out that anthropogenic factors probably have a significant influence on the diversity of the fungal community. The significance of anthropogenic influences is also confirmed by the values of Sørensen similarity index for different localities in the littoral zone. The highest similarity was found between Ohrid Bay and Grasnica ( $\mathrm{S}=63.4$ ), both of which have been under the greatest anthropogenic influence. Matzinger et al. (2006) previously related the increased eutrophication in Lake Ohrid to anthropogenic influences in the catchment area and to progressive use of phosphorus-containing detergents and agricultural fertilizers. Progressive eutrophication was detected according to the phosphorus concentration in water (total phosphorus $\sim 4.5 \mathrm{mg} \mathrm{m}^{-3}$ ). This concentration had grown 3.5 times during the previous century (Matzinger et al. 2007). The dynamics of the fungal community in the littoral zone indicate that aquatic fungi are better represented in eutrophic water, a phenomenon also reported by Ranković (2004). Numerous studies have suggested that fungal diversity in aquatic environments may be affected by physical and chemical characteristics of the water (Czeczuga \& Muszynska 2004, Pascoal et al. 2005, Paliwal \& Sati 2009). The increase in nitrogen and/or phosphorus concentration in oligotrophic freshwaters has been reported to raise species richness (Gulis \& Suberkropp 2003). Some fungi are sensitive to the action of waste substances (Bärlocher 1981, Lockwood \& Filonow 1981, Graca 1994, Dick 2001). Because freshwater fungi are sensitive to changes in water quality, studies on the biodiversity of aquatic hyphomycetes may help to show the effects of water pollution.

The results of this research represent the first data related to the presence of fungi in Lake Ohrid, and they also complement the existing knowledge of its biodiversity in general. They also form the basis for future mycological research of this significant ecosystem.

Acknowledgements. We thank D. Bankoviç for support with the statistical analysis, and M. Tilzer and anonymous reviewers for their suggestions for improving the manuscript.

\section{LITERATURE CITED}

Albrecht C, Wilke T (2008) Ancient Lake Ohrid: biodiversity and evolution. Hydrobiologia 615:103-140 Arnold GR (1968) Methods of collection and studying fresh 
water hyphomycetes. Mycol Phytopathol 2:158-160

Artigas J, Romani AM, Sabater S (2004) Organic matter decomposition by fungi in a Mediterranean forested stream: contribution of streambed substrata. Ann Limnol 40:269-277

Attili DS, Tauk-Tornisiello SM (1994) Occurrence of microfungi during leaf litter decomposition in a cerrado sensu strictu area of São Paulo, Brazil. Rev Microbiol 25:188-194

Bärlocher F (1981) Role of aquatic hyphomycetes in the trophic structure of streams. In: Wicklow DT, Carroll CG (eds) The fungal community: its organization and role in the ecosystem. Marcel Dekker, New York

Bärlocher F (1992) The ecology of aquatic Hyphomyceta. Springer Verlag, Berlin

Barnet H, Hunter B (1998) Illustrated genera of imperfect fungi. $4^{\text {th }}$ edn. APS Press, St Paul, MN

Batko A (1975) Zarys hydromikologii. Panstwowe Wudawnichtwo Naukowe, Warszawa

Booth C (1971) Fungal culture media. In: Booth C (ed) Methods in microbiology. Academic Press, London, p 49-94

Carlile MJ, Watkinson CS (1997) The fungi. Academic Press, New York

Chamier AC (1985) Cell wall degrading enzymes of aquatic hyphomycetes: a review. Bot J Linn Soc 91:67-81

Chamier AC, Dixon PA (1982) Pectinases in leaf degradation by aquatic hyphomycetes: the enzymes and leaf maceration. J Gen Microbiol 128:2469-2483

Coker WC (1969) The Saprolegniaceae. The University of North Carolina Press, Chapel Hill, NC

Čomić L, Rankoviç B, Barbic F (1996) Community of fungi in Gruža reservoir, Yugoslavia. Arch Hydrobiol Spec Issue Adv Limnol 48:105-111

Cooke BW (1963) A laboratory guide to fungi in polluted water, sewage, and sewage treatment systems. Public Health Service Publ 999-WP-1, Cincinnati, OH

Czeczuga B (1991a) Studies of aquatic fungi. XXIII. The mycoflora of Lake Wigry and seven adjacent lakes. Arch Hydrobiol 120:495-510

Czeczuga B (1991b) Studies of aquatic fungi in Lake Sniardwy and eighteen neighboring lakes. Int Rev Gesamten Hydrobiol 76:121-135

Czeczuga B, Muszyńska E (2004) Aquatic zoosporic fungi from baited spores of cryptogams. Fungal Divers 16:11-22

Dick MW (2001) Straminipilous fungi. Kluwer, Dordrecht

Dix NJ, Webster J (1995) Fungal ecology. Chapman \& Hall, New York

Dugan FM (2006) The identification of fungi: an illustrated introduction with keys, glossary and guide to literature. APS Press, St Paul, MN

Gilman IS (1971) Soil fungi. Iowa State University Press, Ames, IA

Graca SAM (1994) Effect of water pollution on assemblages of aquatic fungi. Limnetica 10:41-43

Gulis V, Suberkropp K (2003) Effect of inorganic nutrients on relative contributions of fungi and bacteria to carbon flow from submerged decomposing leaf litter. Microb Ecol 45: $11-19$

Ingold CT (1975) An illustrated guide to aquatic and waterborne hyphomycetes (fungi imperfecti) with notes on their biology. Freshw Biol Assoc Sci Publ 30, Ambleside

Khulbe RD (2001) A manual of aquatic fungi (Chytridiomycetes and Oomycetes). Daya Publishing House, Delhi

Kiziewicz B, Kurzątkowska A (2004) Aquatic fungi and fungus-like organisms isolated from surface waters situated near Białystok in Podlasie Province of Poland using the insect Notonecta glauca as bait. Mycol Balcanica 1: $117-123$
Lockwood JL, Filonow BA (1981) Responses of fungi to nutrient-limiting conditions and to inhibitory substances in natural habitats. Adv Microb Ecol 5:1-61

Lynd LR, Weimer PJ, van Zyl WH, Pretorius IS (2002) Microbial cellulose utilization: fundamentals and biotechnology. Microbiol Mol Biol Rev 66:506-577

Marvanová L (1997) Freshwater Hyphomycetes: a survey with remarks on tropical taxa. In: Janardhanan KK, Rajendran C, Natarajan K, Hawksworth DL (eds). Tropical mycology. Science Publishers, Enfield, NH

Matzinger A, Spirkovski Z, Patceva S, Wüest A (2006) Sensitivity of ancient Lake Ohrid to local anthropogenic impacts and global warming. J Gt Lakes Res 32:158-179

Matzinger A, Schmid M, Veljanoska-Sarafiloska E, Patceva S and others (2007) Eutrophication of ancient Lake Ohrid: global warming amplifies detrimental effects of increased nutrient inputs. Limnol Oceanogr 52:338-353

Middleton J (1943) The taxonomy, host range and geographic distribution of the genus Pythium. Mem Torrey Bot Club 20:1-171

Novevska V (2006) Facultative oligotrophic bacteria as an indicator of the trophic state of Lake Ohrid. Conference on water observation and information system for decision support. BALWOIS, Ohrid. Available at: http://balwois.com/ balwois/administration/full_paper/ffp-812.pdf

Paliwal CP, Sati CS (2009) Distribution of aquatic fungi in relation to physicochemical factors of Kosi River in Kumaun, Himalaya. Nat Sci 7:70-74

> Park B (1972) On the ecology of heterotrophic microorganisms in fresh water. Trans Br Mycol Soc 58:291-299

Pascoal C, Marvanová L, Cássio F (2005) Aquatic hyphomycete diversity in streams of northwest Portugal. Fungal Divers 19:109-128

Perez J, Muñoz-Dorado J, de la Rubia T, Martínez J (2002) Biodegradation and biological treatments of cellulose, hemicellulose and lignin: an overview. Int Microbiol 5: $53-63$

Prasad D, Rajanaika, Joy H, Venkatarangaiah K (2007) Diversity of aquatic fungi in relation to environmental conditions in Tunga River (South India). Researcher 1:54-62

Ranković B (1998) Populations of fungi in some reservoirs in Serbia. Cryptogam Mycol 19:79-86

Ranković B (2004) The fungal community of Lake Sjenica, Serbia. J Freshw Ecol 19:325-332

Raper KB, Fennel DI (1965) The genus Aspergillus. The Williams and Wilkins Co, Baltimore, MD

Raper KB, Thom C (1949) A manual of the Penicillia. The Williams and Wilkins Co, Baltimore, MD

Ristanovic B (1973) Microorganisms of the Neretva River and some of its tributaries. II. Aquatic phycomycetes. Ekologija $7: 55-68$

Ristanovic B (1981) Microbiological studies of Lake Skadarbacteria and fungi populations. In: Karaman SG, Beeton AM (eds) The biota and limnology of Skadar Lake. University of Veljko Vlahovic, University of Wisconsin. GRO Prosveta, Beograd

Salemaa H (1994) Lake Ohrid. In: Martens K, Goddeeris B, Coulter G (eds) Speciation in ancient lakes. Arch Hydrobiol Adv Limnol 44:55-64

Schoenlein-Crusius IH, Piccolo-Grandi RA (2003) The diversity of aquatic hyphomycetes in South America. Braz J Microbiol 34:183-193

Schwerdtfeger F (1975) Ökologie der Tiere. Band 3: Synökologie. Paul Parey Verlag, Hamburg-Berlin

Semenova TA, Terekhova VA (1990) Micromycetes of the Kuibyshev storage lake. I. Estimation of seasonal abundance dynamics by the submerged culture technique. 
Mycol Phytopathol 24:121-124

Sen B (1988a) Fungal parasitism of planktonic algae in Shearwater. III. Fungal parasites of diatoms. Arch Hydrobiol 2-3 (Suppl 79):167-175

Sen B (1988b) Fungal parasitism of planktonic algae in Shearwater. V. Fungal parasites of the green algae. Arch Hydrobiol 2-3 (Suppl 79):185-205

Seymour RL (1969) The genus Saprolegnia. Nova Hedwigia Beih 19

Shearer C, Descals E, Kohlmeyer B, Kohlmeyer J and others (2007) Fungal biodiversity in aquatic habitats. Biodivers Conserv 16:49-67

Sigee CD (2005) Freshwater microbiology: biodiversity and dynamic interactions of microorganisms in the aquatic environment. John Wiley \& Sons, Chichester

Sørensen T (1948) A method of establishing groups of equal amplitude in plant sociology based on similarity of species content and its application to analyses of the vegetation on Danish commons. Videnski Selskab Biol Skr 5:1-34

Editorial responsibility: Max Tilzer,

Konstanz, Germany
Spirkovski Z, Avramovski O, Kodzoman A (2001) Watershed management in the Lake Ohrid region of Albania and Macedonia. Lakes Reserv Res Manag 6:237-242

Steciow MM (2002) A. robusta sp. nov., a new species of Achlya (Saprolegniales, Straminipila) from a polluted Argentine channel. Microbiol Res 157:177-182

Suberkropp K (1991) Relationships between growth and sporulation of aquatic hyphomycetes on decomposing leaf litter. Mycol Res 95:843-850

Thompstone A, Dix NJ (1985) Cellulose activity in the Saprolegniaceae. Trans Br Mycol Soc 85:361-366

Tsui CKM, Hyde KD, Hodgkiss IJ (2001) Colonization patterns of wood-inhabiting fungi on baits in Hong Kong Rivers, with reference to the effects of organic pollution. Antonie Leeuwenhoek 79:33-38

Voronin LV (1989) Saprotrophic fungi in Estonia lakes. Mycol Phytopathol 23:197-202

Voronin LV (2008) Zoosporic fungi in freshwater ecosystems. Inland Water Biol 1:341-346

Submitted: October 13, 2009; Accepted: March 19, 2010

Proofs received from author(s): April 29, 2010 